Журнал«Герстективита інновації наукиљ

(Серія «Гедагогіка», Серія «Гиихологія», Серія«Медицинв»

№(6) 2022

УДК 378:37.02

https://doi.org/10.52058/2786-4952 -2022-1(6)-370-383

Чорнобай Віра Георгіїна старший викладач кафедри філології, Дніпровський державний аграрно-економічний університет, вул. С.Сфремова, 25, м. Дніпро, 49027, тел.: (066) 364-54-53, https://orcid.org/0000-0002-5195-5937

\title{
ЕФЕКТИВНІСТЬ ВИВЧЕННЯ ІНОЗЕМНИХ МОВ У ВНЗ ЗАЛЕЖНО ВІД УМОВ НАВЧАННЯ
}

Анотація. Стаття присвячена проблемі аналізу умов, які впливають успішне вивчення іноземних мов. У статті розглядаються методи навчання, що використовуються 3 початку ХX ст., сучасні підходи та методи навчання іноземної мови, а також принципи організації навчального процесу. Основна увага приділяється наявності спеціальних здібностей та особливостей особистості учнів, які зумовлюють ефективність засвоєння іноземної мови та успішність у оволодінні знаннями, вміннями та навичками в галузі мовної іншомовної діяльності. Даються характеристики мовним, лінгвістичним та іншомовним здібностям. У статті розглядаються питання формування комунікативної та країнознавчої компетенцій, які створюють можливості для тих, хто навчається у професійній та наукових сферах. Значимість англійської мови у світі складно переоцінити. Освоєння нових технологій, інтернаціоналізація всіх сфер життя, розширення міжнародних контактів різко підвищили потребу суспільства в людях, які володіють англійською мовою. При цьому неухильно зростає кількість людей, для яких англійська мова - це не лише засіб спілкування в туристичних поїздках або мова Інтернет комунікації, але й спосіб заявити про себе як про висококваліфікованого спеціаліста у певній сфері, який має досвід ведення справ із зарубіжними партнерами загальновизнаною міжнародною мовою. . Проблема вибору максимально ефективних та раціональних методів викладання іноземних мов, що відповідають сучасним умовам навчання та відповідають вимогам стандартів сучасної освіти, не втрачає своєї актуальності протягом багатьох десятиліть. Відправною точкою будь-якої методичної системи є цілі навчання та відповідні умови навчання. За постановою цілей необхідно враховувати існуючі умови, так щоб досягнення цілей було реальним. Ці два основополагаючих елемента методичної системи визначають вибір методу навчання іноземним мовам.

Ключові слова: метод викладання, стандарт освіти, іноземна мова; мотивація; мовні здібності; лінгвістичні здібності; іншомовні здібності; пам'ять; компетенція; навчальна діяльність; ефективність навчання. 
Chornobai Vira Georgiyivna Senior Lecturer of the Philology Department, Dnipro State Agrarian and Economic University, S. Efremova St., 25, Dnipro, 49027, tel.: (066) 364-54-53, https://orcid.org/0000-0002-5195-5937

\title{
EFFICIENCY OF STUDYING FOREIGN LANGUAGES IN HIGHER EDUCATION INSTITUTIONS DEPENDING ON THE CONDITIONS OF STUDY
}

\begin{abstract}
The article is devoted to the problem of analysis of conditions affecting successful learning of foreign language. The article considers the methods of teaching used since the beginning of the 20th century, modern approaches and methods of teaching a foreign language, as well as the principles of organizing the educational process. The great emphasis is given to the abilities and personality of students, which contribute to the effectiveness of learning a foreign language and to the progress in knowledge, abilities and skills in speech foreign language activities. Language, linguistic and foreign-language abilities are characterized in this article. The article considers issues of formation of communicative and country scientific competences, which create opportunities for students in professional and scientific fields. The importance of the English language in the modern world is difficult to overestimate. The development of new technologies, the internationalization of all spheres of life, and the expansion of international contacts have dramatically increased society's need for people who speak English. At the same time, the number of people for whose English is not only a means of communication on tourist trips or the language of Internet communication, but also a way to declare yourself as a highly qualified specialist in a certain field with experience in dealing with foreign partners in a widely recognized international language. . The problem of choosing the most effective and rational methods of teaching foreign languages that meet modern learning conditions and meet the requirements of modern education standards has not lost its relevance for many decades. The starting point of any methodological system is the objectives of training and their compliance with the conditions of training. Existing conditions must be taken into account when setting goals, so that the achievement of goals is realistic. These two fundamental elements of the methodological system determine the choice of method of teaching foreign languages.
\end{abstract}

Keywords: teaching methods, standard of education, foreign language; motivation; language abilities; linguistic abilities; foreign language abilities; memory; competence; educational activity; learning efficiency.

Постановка проблеми. Нові вимоги до мовної підготовки фахівця означають необхідність удосконалення спеціальних мовних здібностей студентів та підвищення їхньої мотивації до вивчення мов. Навчання іноземної мови сприяє розвитку комунікативних здібностей учнів, необхідні ефективного міжособистісного і міжкультурного взаємодії, у результаті 
розвивається ціннісні орієнтири учнів. Курс іноземної мови (зазвичай англійської) є обов'язковим для вивчення здобувачами вищої освіти у будьякому вищому навчальному закладі України протягом приблизно півтора року (зазвичай три семестри, хоча зараз терміни коригуються). Це означає, що не склавши заліки та іспит 3 англійської мови, жоден студент не може продовжити навчання у ЗВО та отримати диплом, тобто кожен володар диплома про вищу освіту повинен вміти спілкуватися англійською мовою хоча б на середньому рівні (B1 по європейській системі оцінки знань володіння іноземними мовами). Насправді це не зовсім так. У чому ж причина того, що наші студенти (не найдурніші молоді люди, чи не так?) за півтора роки (понад 90 годин навчального аудиторного часу) на виході після отримання оцінки «добре» на іспиті не можуть побудувати навіть найпростішу розмову англійською, чи не можуть аргументувати свою позицію, знайти потрібну інформацію в тексті? Мовна підготовка у ЗВО має дати можливість здобувачам вищої освіти плідно використовувати інформаційний простір, пов'язаний із пошуком та обробкою інформації у своїй подальшій професійній діяльності.

Аналіз останніх досліджень i публікацій. Практика викладання іноземних мов здобувачам вищої освіти показує, що існує низка різнорівневих проблем, які впливають і на організацію процесу навчання, i на його зміст, i на кінцевий результат. Звісно ж важливо відзначити, що проблеми навчання IM (іноземні мови) у неспеціалізованому (немовному) 3BО носять не випадковий, одиничний характер, це прояв системних порушень. Викладач i студент взаємодіють у аудиторії у межах методичної системи, що 3 узагальнених елементів, з урахуванням яких вибудовується конкретний метод (чи технологія) навчання [1], [2]. Методична система диктує вибір методу навчання залежно від цілей навчання та умов, у яких передбачається досягнення зазначених цілей.

Якщо лінгвістичні здібності розглядаються як підсистема когнітивних здібностей учнів, то мовні здібності розглядаються 3 двох точок зору, як генетично закладені в людині та розвиваються в міру іiі розвитку та дорослішання, так і формуються у процесі функціонування та спілкування людини в суспільстві, тобто соціальним шляхом. Мовні здібності людини можна представити як фонетичного, лексичного, граматичного i синтаксичного рівнів відповідно до рівнями мовної системи, якої вони відповідають, i навіть якостей абстрактно-логічного мислення, необхідні виробництва та відтворення промови [3]. Не менш важливі й іншомовні здібності учнів, які, представляють здібності до оперування в процесі спілкування знаковими системами, відмінними від системи рідної мови, зазначила I. А. Зимня[4].

Мовна здатність, що також впливає на ефективність вивчення іноземної мови, розглядається А. А. Леонтьєвим як психофізіологічний механізм, що забезпечує володіння та оволодіння мовою [5]. Більш конкретну 
характеристику мовної здібності дає А. М. Шахнарович, визначаючи це поняття як «багаторівневу ієрархічно організовану функціональну систему, що формується у психіці носія мови у процесі онтогенетичного розвитку» [6].

Мета статті - дослідження особливостей нових технологій викладання іноземних мов у вищих навчальних закладах освіти, інтернаціоналізація всіх сфер життя та зв'язок із умовами навчання, а також виявлення існуючих проблеми, що у подальшому дозволить зрозуміти шляхи їх вирішення.

Виклад основного матеріалу. У процесі вивчення іноземної мови здобувачі вищої освіти опановують методологію пізнання, у них формуються навички критичного мислення та розумової праці, а також навички самоосвіти та ефективної міжкультурної комунікації всіх сфер діяльності (від особистопобутової до професійної). Історично існували десятки підходів та методів у навчанні іноземної мови у ЗВО. На початку ХХ ст. пропагувався прямий метод навчання іноземної мови, у якому іноземні слова безпосередньо асоціювалися безпосередньо з предметами. Сьогодні, завдяки об'єднанню країн у єдину світсистему, вивчення іноземних мов набуло особливої актуальності, внаслідок чого йде активний розвиток та апробування нових підходів та методів навчання іноземним мовам. Важливість володіння іноземною мовою (IM) для сучасного фахівця будь-якої немовної спеціальності диктується часом та відображена у вимогах програмних документів, де іноземна мова фігурує як федеральний компонент державного освітнього стандарту. Ця важливість повинна відбиватися і на кінцевому результаті навчання. Більше того, сучасні вимоги до рівня професійної підготовки фахівця в частині володіння іноземною мовою передбачають не лише вміння розуміти письмову та усну мову, а також писати та говорити, а й уміння ефективно діяти в умовах іншомовного спілкування, що передбачає значно вищий рівень мовної, мовної та позамовної підготовки. Інтерактивний метод розвиває загально-навчальні та комунікативні навички, а також вирішує деякі виховні завдання, оскільки привчає i навчає працювати в команді, прислухатися до чужої думки. Інтерактивне навчання включає різноманітні технології. До найбільш поширених методів/технологій інтерактивного навчання належать: метод проблемного викладу, метод проектів, метод аналізу ситуацій (case study), метод Jigsaw (метод пили), метод мозкового штурму (brain storm session), метод критичного мислення, метод Синквейну, ділові та рольові ігри , метод шести капелюхів, метод Insert (метод індивідуальних позначок, активне читання), метод бліц-опитування та багато інших. Отже, методик викладання іноземних мов дійсно існує безліч. Виникає цілком закономірне питання: який iз методів буде найефективнішим? При цьому цікавою є думка саме студентів, а не викладачів. У межах цього наукового дослідження ми поставили собі дві основні завдання.

Спілкування відбувається щодо змісту навчального матеріалу, організованого певним чином, і за допомогою гнучкої (що бажано) системи способів та прийомів, спрямованих на засвоєння студентами цього матеріалу 
та вміння користуватися ним у різних видах мовної діяльності. Будь-який конкретний навчальний процес має у своєму складі всі елементи методичної системи та співвідноситься 3 нею як реальне та ідеальне, як приватне та загальне. Один із способів перевірити ефективність навчального процесу - це розглянути його з погляду відповідності ідеальній методичній системі. Можна припустити, що навчання IM буде найефективнішим, якщо всі компоненти методичної системи узгоджені та несуперечливі.

Серед найвідоміших можна назвати комунікативно-когнітивний підхід, основоположниками якого є І. Л. Бім та Є. І. Пассов. Цей підхід передбачає опору на наявні комунікативні вміння рідною мовою. Комунікативнокогнітивний підхід, з одного боку, відповідає комунікативним потребам учнів, залежно від вікової категорії, a, з іншого боку, створює умови для свідомого засвоєння іноземної мови. Біля витоків розвитку особистісно-діяльнісного підходу стояли А. Н. Леонтьєв та С. Л. Рубінштейн [5,7]. Даний підхід передбачає врахування психологічних станів і властивостей особистості учня, його мотивів вивчення іноземної мови та діяльнісну форму навчання, що спирається на усвідомленість, цілеспрямованість та активність взаємодії людини з оточуючими.

Таким чином, здобувач вищої освіти, знаходиться в центрі уваги викладача і навчання іноземної мови переломлюється через призму його особистості. Найбільш поширеними сьогодні $є$ інтенсивний та комунікативноорієнтований методи. В основі інтенсивного методу навчання іноземної мови Г. А. Китайгородської лежить психологічний аспект. Цей метод включає принципи ігрової організації навчального процесу, особистісного спілкування та колективної взаємодії. Творчий підхід і реалізація вищезазначених принципів дає можливість подолати труднощі, що виникають при подачі досить великого обсягу матеріалу. В рамках комунікативно-орієнтованого методу навчання іноземних мов учні опановують різні види спілкування в різних комунікативних ситуаціях. Однак необхідно розуміти, що комунікативний акт - це комплексний процес, умовами успішності здійснення якого є рівень мовної та комунікативної компетенції учасників спілкування, а також знання соціокультурних норм та стереотипів мовного спілкування.

Використання комунікативно-орієнтованого методу задає мотиви, цілі та завдання спілкування, що є необхідними умовами комунікації. Застосування творчих завдань під час використання даного методу забезпечує навчання іноземної мови більш продуктивному рівні, наприклад, у професійній сфері діяльності. Нині цей метод передбачає широке використання країнознавчого матеріалу, який формує міжкультурну компетенцію учнів. Ще один не менш цікавий підхід, що набирає популярності останнім часом, а також спирається на країнознавчий матеріал — це лінгвокраїнознавчий підхід при навчанні іноземної мови. Сформованість вищезгаданих компетенцій гарантує сучасному спеціалісту будь-якої сфери діяльності конкурентоспроможність на ринку праці. Доповнюючи одне одного, вони створюють можливість для 
повноцінного спілкування, у якому учні як прилучають наявні лінгвістичні знання знання країнознавчим, a й, нарощуючи i поглиблюючи їх, використовують мову як засіб пізнання. Крім правильно підібраного підходи до навчання іноземної мови не можна не враховувати цілу низку здібностей та умінь учнів, що сприяють ефективному вивченню іноземної мови. Серед них традиційно виділяють лінгвістичні, мовні та іншомовні здібності, а також вербальний інтелект, аналітичну лінгвістичну здатність, фонетичну чутливість тощо. Поняття «лінгвістичні здібності» комплексне та багатоаспектне. Ми, за М. У. Омельяненко, розуміємо під лінгвістичними здібностями сукупність індивідуально-психологічних особливостей особистості студента, які зумовлюють ефективність засвоєння іноземної мови та успішність у оволодінні знаннями, вміннями та навичками у сфері мовної іншомовної діяльності [8]. Лінгвістичні здібності необхідно формувати та розвивати. Одна 3 таких можливостей реалізується у регулярній навчально-пізнавальній діяльності студентів, яка має організувати розумову діяльність на основі алгоритмів та проблемних прийомів. Таким чином, не можна не погодитися 3 С. Л. Рубінштейном, що «результати людської діяльності, узагальнюючись i закріплюючись в людині, входять як "будівельний матеріал" у побудову його здібностей" [7]. Не менш важливий для формування лінгвістичних здібностей та рівень мислення, пам'яті, уяви, сприйняття учня. Здібності учнів виявляються у навчальній діяльності. I, якщо здобувач вищої освіти успішно i ефективно справляється 3 навчальною діяльністю, то можна $з$ упевненістю говорити про наявність у нього не тільки загальних, а й спеціальних здібностей. Здібності у вигляді набору міцних індивідуальних особливостей, відповідають за якість та кінцевий результат діяльності, в якій вони реалізуються.

Іншомовні здібності мають чітку структуру, найважливішим елементом якої $\epsilon$ мотивація студента, наприклад, професійна, пізнавальна чи комунікативна. Також виділяють психічні механізми, що включають рівень розвитку мислення та різних видів пам'яті, чуттєве слухове сприйняття та аналітичні лінгвістичні здібності, що становлять розвиток вербального інтелекту та мовну рефлексію, а також індивідуальні характеристики особистості. Студенти, що мають добре розвинену пам'ять, здатні оперувати великим обсягом лексичного матеріалу, що дозволяє їм вільно вступати у вербальне спілкування. У той час як учні 3 аналітичним складом розуму спираються щодо іноземної мови не на нарощування лексичного обсягу за рахунок синонімів, а на аналіз, структуруючи і поступово ускладнюючи мовний матеріал. Для ефективності навчання іноземних мов необхідно враховувати загально-педагогічні та методичні, соціально-психологічні та індивідуально-психологічні фактори. Перша група факторів стосується структури навчального процесу, методики викладання іноземної мови, терміну навчання, педагогічної майстерності та особистості викладача. Друга група враховує якість соціально-психологічного клімату навчального процесу, умови 
Журнал«Герспективитаіновації наукиљ

(Серія«Гедагогіка», Серія«ГЕихологія», Серія«Медицинв»

№1(6) 2022

навчання, характер взаємодії викладача та учня, взаємодія учня з групою та питання підвищення його мотивації при навчанні іноземних мов, а також сутність психолого-педагогічної діяльності вчителя. Індивідуальнопсихологічні чинники спрямовані на облік вікових та індивідуальнопсихологічних особливостей учнів та практичну реалізацію прийомів побудови навчального процесу 3 іноземної мови 3 їх урахуванням, процесу зміни мотивів та інтересів здобувачів вищої освіти.

До основних методів навчання, що традиційно використовуються в освітньому процесі, відносяться: аудіо-лінгвальний метод, заснований на багаторазовому повторенні мовних моделей [9]; граматико-перекладний метод 3 поглибленим вивченням граматики та великою практикою перекладу [10]; прямий (натуральний) метод, у якому навчання іноземної мови здійснюється без використання рідної мови студента[11]; свідомо зіставний метод, що реалізується через усвідомлення мовних явищ та зіставлення їх із явищами рідної мови; сугесто-педичний метод, у якому використовуються незадіяні резерви людської свідомості; метод фізичного реагування, коли освоєння мовних явищ супроводжується виконанням відповідних фізичних процесів [12]; комунікативний метод, що характеризується максимальним наближенням процесу навчання до процесу реальної комунікації, ретельним відбором тем і ситуацій спілкування, що відображають практичні інтереси та потреби студентів $[10,13,14]$ та ін. студентів як 3 викладачем, а й друг 3 одним, на домінування активності студентів у процесі навчання. Порівняно 3 традиційним навчанням в інтерактивному навчанні використовується інша модель взаємодії викладача та студента: активність викладача поступається місцем активності студентів, а завданням викладача стає створення умов для ініціативи студентів, спонукання до самостійного пошуку.

Найцікавішим 3 погляду застосування на практичних заняттях у вузі видався інтерактивний метод навчання. Об'єктом нашого інтересу стали 3 технології: технологія «Group Story» (технологія «Групове оповідання»), технологія «Brain storming» (технологія «Мозковий штурм») у поєднанні з методом проектування, та метод «Six thinking hats» (метод «Шість капелюхів»).

Сутність технологіï «Group Story» - командна робота. Академічна група студентів була розбита на кілька підгруп (команд). Кожна команда отримала аркуш паперу, на якому було написано першу пропозицію - початок майбутнього групового оповідання. За обмежений проміжок часу команди повинні були дописати одну пропозицію до оповідання, а потім за сигналом передати лист наступній команді. Після того, як розповіді були написані, команди зачитували, а потім перекладали групові історії. На завершення було обрано найкращі оповідання шляхом відкритого голосування. Залежно від рівня володіння іноземною мовою, обговорення частин оповідань велося англійською мовою. Студенти виявили вміння працювати в команді.

Друга методика - технології «Brain-storming» у поєднанні 3 методом проектування - усі ідеї записуються на дошці. Оскільки метод мозкового 
штурму передбачає можливість подальшого розвитку ідей, то на наступному етапі роботи студенти обирали найкращі ідеї 3 усіх запропонованих, аргументуючи, чому та чи інша ідея справді краща. Після цього група ділилася на команди, які за певний проміжок часу мали розробити проект-план 3 відкриття нового бізнесу, спираючись на висловлені раніше ідеї. При цьому важливо було, щоб під час обговорення студенти розмовляли англійською. Після закінчення роботи кожна з команд представляла свої розроблені бізнесплани. Робота у командах велася у різних режимах: після попереднього обговорення загальної ідеї частина команд розділили завдання кілька частин за кількістю членів у команді, кожен учасник розробляв свою частину. Інші команди розробляли свій бізнес-план спільно, розподіливши ролі: один студент пише, другий - шукає слово у словнику тощо. Незалежно від вибраного режиму роботи всі команди встигли розробити проект у позначений час. На етапі мозкового штурму не всі студенти групи виявляли активність, то на етапі командної роботи кожен з них виконав своє комунікативне завдання, розуміючи, що він, як і будь-який інший член команди, відповідає за загальний результат. У традиційних методах викладання найбільш полюбились студентам читання та переклади (двонаправлені), також лексичні вправи. Складання та презентація діалогічних/монологічних висловлювань та виконання письмових завдань подобаються найменше. Але студенти вважають для себе говоріння найкориснішим видом діяльності щодо іноземної мови. Для багатьох студентів процес говоріння пов'язаний 3 негативними емоціями, страхом помилитися, не впоратися 3 поставленим завданням, i, як наслідок, зазнати комунікативної невдачі у поєднанні 3 низькою оцінкою відповіді. Отже, необхідність використання інтерактивних методик викладання іноземної мови на практичних заняттях є необхідною, оскільки дає чудовий результат.

Практичне володіння мовою як засобом спілкування у професійній сфері, яке включає читання літератури за спеціальністю та суміжними галузями науки; переклад за спеціальністю та широкому колу суспільно значущих проблем; участь в усному спілкуванні в рамках тем та ситуацій загального характеру, що визначаються держстандартами; практична реалізація мовних (системних) знань, умінь та навичок в умовах іншомовного спілкування в усному (монолог, діалог, полілог, дискусія тощо) та письмовій мові (анотація, реферат, тези, повідомлення, приватний лист, діловий лист, біографія і т.д.).

Студенти повинні мати уявлення про повсякденно літературний, офіційно діловий, науковий стиль; стилі художньої літератури; володіти знаннями про культуру і традиції країн мови, що вивчається; знати правила мовного етикету. Всі ці вміння та знання забезпечуються граматичними навичками, тобто передбачають досить вільне володіння системою мови на всіх рівнях, як у рецептивному, так i у продуктивному режимах. Основними умовами, що впливають досягнення цілей, тобто на якість володіння іноземною мовою, $є$ якісні та кількісні характеристики контингенту студентів; кількість 
аудиторних годин, що відводяться на дисципліну та ін. Рівень матеріальнотехнічної бази, оснащеність технічними засобами навчання також важливі.

Середній студент-першокурсник не може розмовляти англійською мовою. Його лексичний запас мінімальний, а наявні слова не може коректно вжити у розмові. У найкращому разі студент використовує найпростіші синтаксичні конструкції, при цьому не уникаючи ні граматичних, ні фонетичних, ні комунікативних помилок. Найбільшу складність, як свідчить досвід, представляє вибір дієслова і вживання їх у потрібної часо-видовій формі. Це говорить, насамперед, про несформованість у свідомості студентівпершокурсників уявлення про систему англійської мови в частині граматичного часу. Власне, як і інших простіших граматичних явищ. Все це змушує викладача ЗВО наголошувати на компенсаторній функції навчання іноземної мови, а іншими словами, виправляти недоліки шкільної освіти, «доучувати», а десь і переучувати здобувачів вищої освіти. На жаль, у середнього студента буде невисока мотивація до оволодіння іноземною мовою. Здобувачі вищої освіти знають про можливості, що їх відкриває знання іноземної мови. Через володіння іноземною мовою вони можуть удосконалюватися і у професійному, і загальнокультурному та пізнавальному аспектах; вирішувати прагматичні завдання та просто використовувати його в неформальному спілкуванні. Знання англійської мови передбачає і розширене користування мережею Інтернет, як джерелом додаткової інформації для поповнення багажу професійних знань, та реальні можливості виїзду за кордон, як для вдосконалення своєї мовної підготовки, так і для професійних стажувань та навчання у закордонних навчальних закладах, а також інші можливості , що у результаті можуть сприяти швидкому кар'єрному зростанню. Кар'єрне зростання займає одне 3 перших місць у рейтингу життєвих домагань молодих людей. Але все це, на жаль, не сприяє формуванню у студентів внутрішньої мотивації. Сдиним реальним шляхом підвищення мотивації студентів $є$ формування вони інтересу до занять методичними засобами, тобто створенням зовнішньої мотивації, яка, як відомо, набагато менш ефективна, ніж внутрішня [14].

Ідеальні умови викладання в 3ВО, коли викладач може впливати на процес функціонування методичної системи, використовуючи різні засоби навчання, способи та прийоми, їх комбінації та можливості варіювання. У межах цієї підсистеми викладач найповніше може розкрити свій творчий потенціал, реалізувати індивідуально-особистісний компонент процесу навчання. Викладач шукає нові форми роботи 3 навчальним матеріалом, способи його розробки та презентації. Передбачається, що навчання професійного спілкування англійською мовою здійснюється на базі вже достатньо сформованих мовних і мовних умінь і навичок, з якими вчорашній випускник школи приходить до ЗВО[15]. Оскільки професійне спілкування (дискурс) розуміється в сучасній лінгвістиці як складний трикомпонентний феномен, що складається з учасників дискурсивного спілкування (автор та 
реципієнт), тексту, з приводу якого здійснюється спілкування, та ситуації, в якій відбувається це спілкування, то від його учасників потрібно не тільки базове володіння іноземною мовою, а й уміння застосовувати практично спеціальні граматичні структури та знання спеціальних правил вживання лексики.

Реальний процес навчання іноземної мови взагалі та професійному іншомовному дискурсу зокрема в умовах немовного ЗВО має суттєві недоліки системного характеру, тобто в основних своїх елементах не відповідає вимогам методичної системи. Головним недоліком $є$ неузгодженість цілей та умов навчання, причому можливості викладача впливати на структуру та утримання цих підсистем зводяться до мінімуму через їх сутнісні особливості та об'єктивно заданий характер. Викладачеві також задаються зміст навчального матеріалу та його організація. Але в цьому відношенні викладач більш вільний, хоч i обмежений матеріалом конкретного навчальнометодичного комплексу чи робочої програми. Найбільш повно викладач може проявити себе у плані творчого використання засобів навчання, форм та способів взаємодії зі здобувачами вищої освіти. Але в силу розглянутих у статті причин це лише певною мірою може вплинути на ефективність та якість процесу навчання іноземної мови у 3ВО. В результаті, у вищій школі розвивається тенденція поступового переходу інформаційно-освітніх середовищ із закритого стану на все більш відкритий, з частковим або повним перенесенням навчального процесу в Інтернет, збереженням освітніх цілей та завдань, придбанням все більш прозорих кордонів для здобувачів вищої освіти та громадськості. Створення відкритого інформаційно-освітнього середовища обумовлено не так накопиченням комп'ютеризованих робочих місць і точок доступу всередині вузу, як пріоритетним зовнішнім доступом до його освітніх ресурсів та створенням повсюдної інфраструктури. До облаштованих робочих місць студентів та викладачів на території ЗВО мають додаватися точки доступу, організовані самими студентами та викладачами за межами 3ВО. Найбільш повно даним умовам відповідає мережа Інтернет, що зумовлює використання інтернет-ресурсів та інтернет-сервісів як технологічну основу відкритого інформаційно-освітнього середовища та забезпечує їй автоматичне оновлення у технологічному плані та відповідність потребам часу та суспільства.

Вища освіта схильна до тенденції інформатизації і реалізує свої завдання в ризикових ситуаціях. Так, фактично, перенесення навчального процесу у відкрите інформаційне середовище та Інтернет зумовив розвиток електронного навчання та неконтактних форм проведення занять, впровадження у навчальний процес відкритих освітніх ресурсів як основних джерел знань, реалізацію індивідуального підходу до кожного учня, перехід від традиційної парадигми навчання до нової парадигми, створення умов для самостійного «добування» знань та спільної освітньої діяльності здобувачів вищої освіти та викладачів. Маючи безперечні переваги перед традиційною формою навчання 
Журнал«Герспективитаіновації наукиљ

(Серія«Гедагогіка», Серія«ГЕихологія», Серія«Медицина»

№1(6) 2022

і створюючи умови для безперервного та вільного розвитку особистості, електронне навчання несе з собою певні труднощі, проблеми та ризики, що знижують якість освітніх результатів. У нових умовах перебігу навчального процесу першочерговим завданням педагогів стає виявлення переліку можливих проблем, облік яких дозволить підвищити якість вищої освіти. При цьому дані проблеми $\epsilon$ не лише психолого-педагогічними, а й загальнокультурними, чіпаючи як окрему особистість, так і суспільство загалом 3 різних аспектів - від культури взаємодії у мережевому співтоваристві до валеологічних проблем. На наш погляд, проблеми, що виникають при переносі навчального процесу в Інтернет, носять організаційний, методичний i загальнокультурний характер. Проблеми організаційного характеру виявляються i на рівні побудови вузівських мережевих кластерів та під час організації окремого відкритого освітнього курсу.

Висновки. Ряд здібностей можна розвивати, а деякі здібності, наприклад, фонетична чутливість є генетично закладеними, i, отже, незалежними від інших здібностей. Ступінь розвитку та прояви тих чи інших здібностей у студентів може змінюватись. А грамотний розвиток та поєднання певних здібностей може призвести до значних результатів у вивченні іноземної мови. Студенти, які мають гарну пам'ять і високий рівень аналітичних здібностей, а також почуття мови та значний рівень мовної компетенції в рідній мові, здатні досягти високих результатів у вивченні іноземної мови, однак таке поєднання здібностей $є$ ідеальним. Найчастіше у студентів розвинена одна чи дві вищезгадані здібності. Незалежно від обраного режиму роботи, всі команди встигли розробити проект у позначений час. Слід зазначити, що, якщо на етапі мозкового штурму не всі студенти групи виявляли активність, то на етапі командної роботи кожен студент виконав своє комунікативне завдання, розуміючи, що він, як і будь-який інший член команди, відповідає за загальний результат.

Третім методом інтерактивного навчання - метод Шести капелюхів (Six thinking hats). Після етапу поділу на групи студенти отримали роздатковий матеріал, в якому були представлені опис методу англійською мовою та ситуація для обговорення (типи екологічного забруднення). У роздатковому матеріалі були розписані значення кожного 3 капелюхів: білий капелюх (факти), чорний капелюх (критика, негативні сторони), жовтий капелюх (пошук переваг, позитивних сторін), червоний капелюх (вираження почуттів, емоцій), зелений капелюх (нові ідеї), синій капелюх (управління процесом роботи). Далі капітан кожної команди вибрав жетон із кольором першого капелюха команди. На спільному обговоренні було вирішено, що синій капелюх (капелюх організатора) носитиме викладач. Таким чином, кожній команді дістався один із п'яти капелюхів. На наступному етапі, залежно від кольору капелюха, студенти розглядали ситуацію 3 різних боків, приміряли різні ролі. На обговорення кожного капелюха давалося 7 хвилин, після чого 
команди мінялися капелюхами. Процес обговорення у всіх командах проходив одному режимі: розробка ідеї усіма учасниками, запис відповіді одним студентом, пошук незнайомих слів у електронному словнику іншими членами команди. Робочі мови - англійська, українська. У разі потреби викладач давав консультації. Записи велися англійською. Процес презентації результатів роботи був організований за принципом зміни капелюхів: спочатку всі команди представили свою роботу в рамках білого капелюха, потім зеленого, синього, червоного, жовтого. Наприкінці всі обговорювали, у кого найвдаліше вдалося подивитися на ситуацію крізь призму того чи іншого капелюха. Найбільш «простий» виявився білий, червоний і зелені капелюхи. Чорний i жовтий капелюхи були дещо переповнені емоційністю та чуттєвістю червоного капелюха. Дана технологія отримала позитивні оцінки від студентів як один із найцікавіших способів розвитку комунікативних навичок. Використання макетів капелюхів внесло елемент гри, до якої із задоволенням включилися студенти. Студенти вивчають іноземну мову, щоб спілкуватися при поїздках за кордон (57\% респондентів), знайти хорошу роботу (43\% респондентів), спілкуватися по інтернету (15\% респондентів), читати літературу в оригіналі (11\% респондентів) та щоб сдати сесію (40\% респондентів), а ще "для загального розвитку", "для підвищення інтелекту", "просто так". Читання, аудіювання, письмо, вивчення граматики/ лексики як основи для успішної усної та письмової комунікації - ідеальна суміш класичних та інноваційних технологій.

Навчальний процес, що проводиться у відкритих інформаційноосвітньому середовищі, має свої особливості, зумовлені відсутністю обмежень на час i місце навчання, обсягом матеріалу, що вивчається, можливістю побудови унікальної траєкторії «добування» знань. У зв'язку з цим перед викладачем постають такі завдання: 1) вибір якісних джерел матеріалу, що використовується для супроводження навчального процесу; 2) розробки методики проведення занять 3 урахуванням різноманітності навчальних ситуацій, що виникають у цьому процесі, кількість і суть яких не завжди можна припустити; 3) пошук педагогічних методів та освітніх технологій, за допомогою яких можна керувати навчанням віддалено та протистояти небажаним явищам у ньому; 4) зміна підходів до забезпечення та контролю якості навчання в мережі.

\section{Лimepamypa:}

1. Бім І.Л. Методика навчання іноземних мов як наука та проблеми шкільного підручника. - М., 1977. - 202 с.

2. Китайгородська Г.А. Інтенсивне навчання іноземних мов: теорія та практика. - М.: Poc. м., 1992. - 254 с.

3. Бім Бад Б.М. Інтерактивне навчання// Педагогічний енциклопедичний словник. -М., 2002. - 107c. - URL: http://pedagogical_dictionary.academic.ru//1291/Інтерактивне_навчання.[Дата звернення 15.02.2016].

4. Зимня, I. А. Психологічні аспекти навчання мовленню іноземною мовою: книга для вчителя. - 2-ге вид. - М: Просвітництво, 1985. - 176с. 
5. Леонтьєв, А. А. Основи психолінгвістики. - М: Вид. центр "Академія", 2005. - 204с.

6. Шахнарович, А. М. До проблеми мовної здібності (механізму) // Людський фактор у мові: мова та породження мови. - М: Наука, 1991. - с.45-49

7. Рубінштейн, С. Л. Буття та свідомість. - М: Вид-во АН СРСР, 1957.

8. Омельяненко, Н. В. Формування лінгвістичних здібностей у учнів старших класів: дис. канд. психол. наук. - М.: Київ, 1986. - URL: http://childpsy.ru/dissertations/id/19327.php.

9. Гусєвська Н. Ю. Еволюція Методів навчання іноземної мови// Вчені записки ЗабГУ. -2013. -№ 6 (53). - С.167-171.

10. Sierra Fernando Cerezal. Foreign languages teaching methods: some issues and new moves. -URL: http://www.encuentrojournal.org/textos/8.7.pdf.-[Датаобращения15.02.2016].

11. M.E.S. Elizabeth. Methods of teaching English. -New Delphy: Discovery Publishing House, 2007. -373 c. -URL: https://books.google.ru/.-[Датаобращения11.01.2016].

12. Кузнєцова Р. А. Дослідження на тему “"Суггестопедичний підхід до навчання іноземних мов" // 12FAN.RU - URL: http://12fan.ru/2323959193.html.-[Дата звернення 01.02.2016].

13. Використання методу TPR (повного фізичного реагування) на заняттях // English for little ones. -URL: http://englishlittle.ru/poigraem/podvizhnyeigry/ispolzovaniemetodatpr. html.-[Дата звернення 15.02.2016].

14. Сопова $€$. Технології інтерактивного навчання під час уроків іноземної мови // Іноземні мови. IYAZYKI.RU. FOREIGNLANGUAGES: електронний журнал. -2013. -URL: http://iyazyki.prosv.ru/2013/03/interactivelanguage/.-[Дата звернення 15.02.2016]

15. Новосельцева Н. Н. Інтерактивні методи навчання англійської мови у вузі // Сучасні технології навчального процесу у вузі: тези наукової міжнародної конференції, 2012. - URL: http://www.nmk.ulstu.ru/ index.php?tezis=2009421\&item =2\&god=2012.-[Дата звернення 13.02.2016]

\section{References:}

1. Bim I.L.(1977). Metodika navchannya inozemnih mov yak nauka ta problemi shkil'nogo pidruchnika [Methods of teaching foreign languages as a science and problems of school textbooks]. - M. - 202 [in Russian].

2. Kitajgorods'ka G.A. (1992) Intensivne navchannya inozemnih mov: teoriya ta praktika [Intensive learning of foreign languages: theory and practice] - M.: Ros. m. - 254 [in Russian].

3. Bim Bad B.M. (2002) Interaktivne navchannya [Interactive learning]. Pedagogichnij enciklopedichnij slovnik. -M. - 107 [in Russian].

URL: http://pedagogical_dictionary.academic.ru//1291/Interaktivne_navchannya.-[Data zvernennya 15.02.2016].

4. Zimnya I. A.(1985) Psihologichni aspekti navchannya movlennyu inozemnoyu movoyu: kniga dlya vchitelya [Psychological aspects of teaching speech in a foreign language: a book for teachers] - 2-ge vid. - M: Prosvitnictvo. - 176[in Russian].

5. Leont'€v A. A.(2005) Osnovi psiholingvistiki [Fundamentals of psycholinguistics]. $M$ : Vid. centr "Akademiya". - 204[in Russian].

6. Shahnarovich A. M.(1991) Do problemi movnoï zdibnosti (mekhanizmu) [To the problem of language ability (mechanism)]. Lyuds'kij faktor u movi: mova ta porodzhennya movi. - M: Nauka. - 45-49[in Russian].

7. Rubinshtejn S. L. (1957) Buttya ta svidomist' [Being and consciousness] - $M$ : Vid. AN SRSR [in Russian].

8. Omel'yanenko N. V.(1986) Formuvannya lingvistichnih zdibnostej u uchniv starshih klasiv [Formation of linguistic abilities in high school students]. Dis. kand. psihol. nauk. - M.: Kï̈v. [in Russian]. - URL: http://childpsy.ru/dissertations/id/19327.php.

9. Gusevs'ka N. YU.(2013) Evolyuciya Metodiv navchannya inozemnoï movi [Evolution of Foreign Language Teaching Methods]. Vcheni zapiski ZabGU. - № 6 (53). -167-171. [in Russian]. 
10. Sierra Fernando Cerezal. Foreign languages teaching methods: some issues and new moves. URL: http://www.encuentrojournal.org/textos/8.7.pdf.-[Dataobrashcheniya15.02.2016]. [in English].

11. M.E.S. Elizabeth. Methods of teaching English. -New Delphy: Discovery Publishing House, 2007. -373 s. -URL: https://books.google.ru/.-[Dataobrashcheniya11.01.2016]. [in English].

12. Kuznecova R. A. Doslidzhennya na temu "Suggestopedichnij pidhid do navchannya inozemnih mov" [Research on "Suggestopedic approach to foreign language teaching"]. 12FAN.RU - URL: http://12fan.ru/2323959193.html.-[Data zvernennya 01.02.2016]. [in Russian].

13. Vikoristannya metodu PFR (povnogo fizichnogo reaguvannya) na zanyattyah [Using the TPR method (full physical response) in the classroom English for little ones]. -URL: http://englishlittle.ru/poigraem/podvizhnyeigry/ispolzovaniemetodatpr.html.-[Data zvernennya 15.02.2016].

14. Sopova Ye.(2013) Tekhnologiï interaktivnogo navchannya pid chas urokiv inozemnoï movi [Interactive learning technologies during foreign language lessons]. Inozemni movi. IYAZYKI.RU. FOREIGNLANGUAGES: elektronnij zhurnal. -. -URL: http://iyazyki.prosv.ru/ 2013/03/interactivelanguage/.-[Data zvernennya 15.02.2016]

15. Novosel'ceva N. N.(2012) Interaktivni metodi navchannya anglijs'koï movi u vuzi [Interactive methods of teaching English at the university]. Suchasni tekhnologii navchal'nogo procesu u vuzi: tezi naukovoï mizhnarodnoï konferenciï. - URL: http://www.nmk.ulstu.ru/ index.php?tezis=2009421\&item $=2 \&$ god=2012. $-[$ Data zvernennya 13.02.2016] 